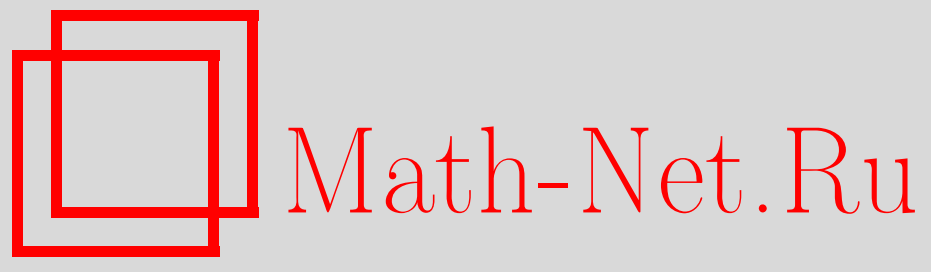

Конкурс Московского математического общества 2014 года среди молодых математиков, УМH, 2014, том 69, выпуск 2, 208

DOI: https://doi.org/10.4213/rm9606

Использование Общероссийского математического портала Math-Net.Ru подразумевает, что вы прочитали и согласны с пользовательским соглашением http://www . mathnet.ru/rus/agreement

Параметры загрузки:

IP : 3.89 .185 .249

26 апреля 2023 г., 04:54:03

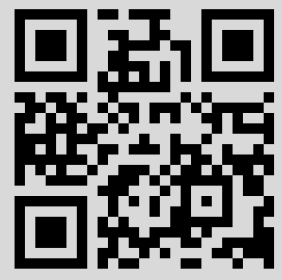




\section{Конкурс Московского математического общества 2014 года среди молодых математиков (см. http://mms.mathnet.ru/conc.php)}

Премии Московского математического общества присуждаются молодым ученым за работу или цикл работ по математике, представляющих значительный научный интерес. Молодым считается ученый, которому в календарном году присуждения премии исполняется не более 30 лет.

Представлять работу или цикл работ на конкурс может любой член ММО.

Представляющий до 15 июня 2014 года присылает по электронному адресу konkursMMO@gmail.com:

- описание работ(ы) (если это цикл работ, то еще его общее название и список выдвигаемых работ);

- текст(ы) выдвигаемых работ в формате PDF;

- список возможных рецензентов и/или рекомендации других математиков (членство в ММО от рецензентов не требуется).

Решение о присуждении премии будет принято на заседании Правления ММО в сентябре 2014 года.

Денежная часть премии формируется при поддержке Российско-французской математической лаборатории им. Ж.-В. Понселе (CNRS и HМУ). 